\title{
PRESENCE OF ORGANOPHOSPHATE INSECTICIDES IN FISH OF THE AMAZON RIVER
}

\author{
Nicolas SOUMIS ${ }^{1 *}$, Marc LUCOTTE ${ }^{1}$, Delaine SAMPAIO ${ }^{2}$, Diane CRUZ \\ ALMEIDA $^{2}$, Dalie GIROUX ${ }^{3}$, Silmara MORAIS ${ }^{2}$, Pierre PICHET ${ }^{4}$
}

\begin{abstract}
Trace levels of three organophosphate insecticides (OPI) were detected in eight fish species from the region of Santarém, State of Pará, Brazil. Individual concentrations of OPI in fish ranged from less than the detection limit to 2,1 ppb. Mean concentrations of chlorpyrifos, malathion, and methyl-parathion were $0,3 \pm 0,3,0,1 \pm 0,1$, and $0,3 \pm 0,3 \mathrm{ppb}$, respectively. Pellona flavipinnis, the largest and fattest piscivorous species analyzed, was the most contaminated. Since an inhabitant of this Amazonian region consumes $220 \mathrm{~g}$ of fish per day on average, ingested doses of chlorpyrifos, malathion, and methyl-parathion may reach up to 308,220 , and $462 \mathrm{ng} \cdot \mathrm{d}^{-1}$, respectively. Compared to acceptable daily intakes (ADI), quantities of OPI absorbed via fish consumption on a daily basis are far below deleterious levels. We estimated that even considering the highest OPI contents detected, the average daily fish consumption of an adult of $60 \mathrm{~kg}$ would have to increase by ca. 1950,5450 , and 2600 times to reach ADI of chlorpyrifos, malathion, and methyl-parathion, respectively. Neither fish diet nor fish lipid content enabled us to completely explain the interspecific differences observed.
\end{abstract}

Key-Words: Brazilian Amazon, fish contamination, organophosphate insecticides, acceptable daily intake (ADI), human alimentation.

\section{Presença de inseticidas organofosforados nos peixes do Rio Amazonas}

RESUMO - As concentrações de três inseticidas organofosforados (IOF) foram determinadas em oito espécies de peixes da região de Santarém, Estado do Pará, Brasil. As concentrações individuais de IOF dos peixes situam-se entre abaixo da limite de detecção e 2,1 ppb. As concentrações médias de clorpirifós, malathion e metil parathion foram respectivamente de $0,3 \pm$ 0,3, 0,1 $\pm 0,1$ e $0,3 \pm 0,3 \mathrm{ppb}$. Pellom Flavipinnis, a espécie piscívora de maior tamanho e mais gordurosa, apresentou as concentrações mais elevadas. Considerando que um morador dessa região da Amazônia brasileira consome em média $220 \mathrm{~g}$ de peixe por dia, as doses de clorpirifós, malathion e metil parathion podem atingir respectivamente 308, 220 e $462 \mathrm{ng} \cdot \mathrm{d}^{-1}$. Tendo em conta as "doses diárias aceitáveis" (acceptable daily intakes - ADI), as quantidades diárias de IOF absorvidas via consumo de peixe estão muito abaixo dos níveis perigosos para a saúde humana. Nós estimamos que mesmo com o teor mais elevado de IOF detectado, o consumo diário médio de peixe de um adulto de $60 \mathrm{~kg}$ teria que aumentar cerca de 1950,5450 e 2600 vezes para atingir as respectivas ADI de clorpirifós, malathion e metil parathion. Nem o hábito alimentar dos peixes e nem o seu teor de gorduras podem explicar completamente as diferenças interespecíficas observadas.

Palavras-Chave: Baixo Amazonas, contaminação em peixes, inseticidas organofosforados, doses diárias aceitáveis (ADI), alimentação humana.

\footnotetext{
${ }^{1}$ Author to whom correspondence should be addressed. Tel. : (514) 987-4080 Fax: (514) 987-3635

E-mail: nicolas.soumis@internet.uqam.ca

${ }^{2}$ Institute of Environmental Sciences/GEOTOP, University of Québec in Montréal (UQAM), PO Box 8888, succ. Centre-Ville, Montréal, Québec, H3C 3P8, Canada.

${ }^{3}$ Laboratory of Environmental Biology, Federal University of Pará, Campus of Santarém, Santarém, PO Box 241, CEP 68040-060, Pará, Brazil.

${ }^{4}$ Department of Political Science, UQAM, PO Box 8888, succ. Centre-Ville, Montréal, Québec, H3C 3P8, Canada.

${ }^{5}$ Department of Chemistry, UQAM, PO Box 8888, succ. Centre-Ville, Montréal, Québec, H3C 3P8, Canada.
} 


\section{INTRODUCTION}

We previously performed a study of pesticide consumption in the region of Santarém, an important urban center of the Lower Amazon, Brazil (Soumis et al., 2000). Based on surveys among several local crop producers and agricultural suppliers, this study established that besides other pesticides such as fungicides and herbicides, organophosphate insecticides (OPI) were the most common compounds into the pesticide arsenal of this region, their consumption reaching ca. $2000 \mathrm{~kg} \cdot \mathrm{year}^{-1}$ (active ingredients). The importance of these insecticides is also reflected by pesticide consumption figures for Brazil gathered by the Food and Agriculture Organization (FAO) that indicate an upward trend in the use of OPI between 1991 (1 850 tons) and 1995 (5 384 tons $)^{1}$. These insecticides are currently used on crops established on floodplains (várzeas) of the Amazon River. Várzea designate the portion of land along rivers which is flooded during the rainy season. Annual floods carry large amounts of nutrient-rich Andean sediments which deposite on várzeas, a fertilizing phenomenon that ensures an enhanced agricultural potential for these environments (Furch, 1997; Ohly and Junk, 1999; Zarin, 1999).

Apart from supporting agriculture, várzeas also represent important fishing sites in view of their abundant and diverse ichtyofauna (Ruffino, 1996; Cerdeira et al., 1997; Ruffino et al., 1998). Now the multiple use of this environment may be problematic since the contamination of fish by OPI is likely to occur for several reasons. First, várzea crops are located in the vicinity of aquatic ecosystems. Hence, wind drift, volatilization, and frequent heavy rainfalls in the Amazon Basin (IBGE, 1977, in Salati, 1985; Ohly, 1987) may cause OPI to reach streams and lakes nearby crops (Racke, 1992). Second, OPI re- main in their original form long enough (from several days to a few months) to allow them to move away from their application site. Third, many OPI are hydrophobic compounds; in aqueous media, they have much more affinity for the biological compartments (Sabharwal and Belsare, 1986; Cowgill et al., 1991).

Basic information on the pesticide burdens in fish remains of first concern in the Lower Amazon as fisheries represent one of the principal economic activities in this region, and as fish is the main source of animal proteins in the diet of local populations (Saint-Paul and Bayley, 1979; Ferreira et al., 1996; Isaac et al., 1996). According to our knowledge, very few studies has yet been conducted in order to assess the concentration of agricultural pesticide in the Amazonian ichtyofauna (Torres et al., 2002). Considering a situation which may jeopardize the health of the local populations and alter an important pillar of the regional economy, the present study constitutes a preliminary assessment of the ichtyofauna contamination by three OPI commonly used on várzea crops : chlorpyrifos $(O, O$-diethyl $O$ (3, 5, 6-trichloro-2-pyridyl) phosphorothioate; CAS : 2921-88-2; $\mathrm{K}_{\text {ow }}: 158$ 489), malathion (O,O-dimethyl $S$-(1, 2-dicarbethoxyethyl) phosphorodithioate; CAS : 121-75-5; $\mathrm{K}_{\text {ow }}$ : 776), and methyl-parathion $(O, O$-dimethyl $O$ (4-nitrophenyl) phosphorothioate; CAS : 298$00-0 ; \mathrm{K}_{\text {ow }}: 1288$ ). The following objectives were pursued : 1) to obtain a portrait of the fish contamination by OPI in the region of Santarém; 2) to compare the results obtained with acceptable daily intakes ${ }^{2}$ (ADI) in order to determine if the daily doses absorbed by local populations reach a theoretically critical level; 3) to verify the existence of significant interspecific differences in contamination levels and to assess some biological factors that may be responsible for such differences.

${ }^{1}$ According to FAOSTAT, a FAO's database available on the Web (http://apps.fao.org/page/collection). Data from FAO are only available from 1991 to 1995 .

${ }^{2}$ Acceptable daily intake was defined by the World Health Organization (WHO) as the daily intake of a chemical which, during an entire lifetime, appears to be without appreciable risk on the basis of all known facts at the time (WHO, 1962, in Klaassen and Eaton, 1991). ADI is expressed in mg of chemical by $\mathrm{kg}$ of the consumer body. 


\section{STUDY AREA}

Located at the confluent of the Tapajós and the Amazon Rivers in the State of Pará, Santarém $\left(2^{\circ} 25^{\prime} \mathrm{S}, 54^{\circ} 43^{\prime} \mathrm{W}\right)$ is the principal urban center of the Lower Amazon. This region was selected for many reasons. First, an important concentration of agricultural activities take place around Santarém (Scatena et al., 1996). Second, this region also encompasses one of the greatest concentrations of várzeas of the Brazilian Amazon. Third, as the largest fishing port of the Lower Amazon, Santarém receives the catches from 14 municipalities along the Amazon River (Isaac et al., 1996; Ruffino et al., 1998). It is thus possible to collect at Santarém's fish markets specimens coming from the whole region.

\section{MATERIAL AND METHODS}

The sampling campaign was conducted by the end of September of 1998, during the low water season. At that time of year, as river recedes to its lowest level (Fig. 1), the whole várzeas are free of water and agricultural activities attain its optimum. Consequently, the highest pesticide consumption is expected to be found during this season. One undred and twenty fresh specimens, equally distribu ted between eight species (Tab. 1), were bought from a fish market located in the port of Santarém during a five-day sampling. According to salemen and fishermen, specimens collected were known to belong from the region.

Figure 1 - Fluctuations of water level for 1998. Measurements were made twice a day at the Portobrás' wharf in Santarém, located at the confluence of the Amazon and Tapajós Rivers (Data from Delegacia da Capitania dos Portos dos Estados do Pará e Amapá em Santarém).

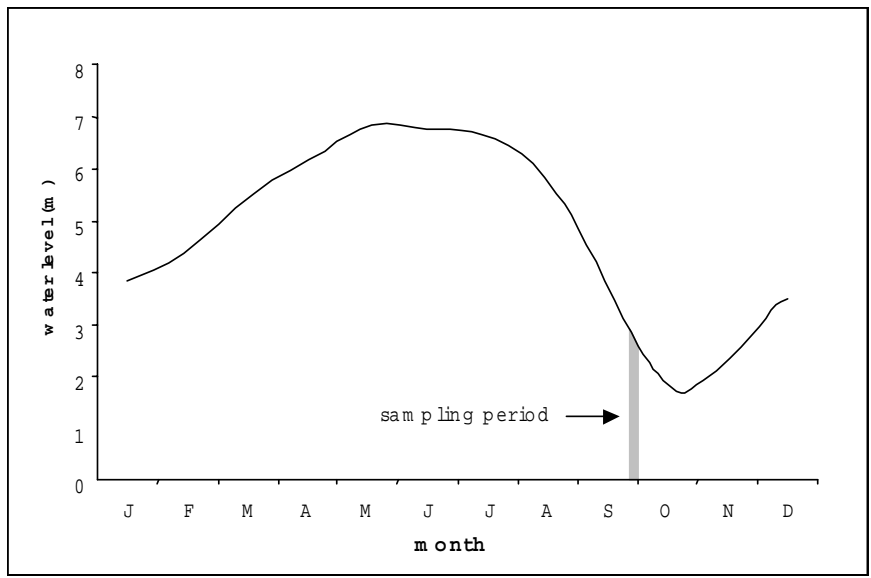

Table 1 - Names, diet and lipid content of fish species sampled from the market of Santarém.

\begin{tabular}{|c|c|c|c|}
\hline Scientific name & Common name (Brazilian) & Diet & Lipid content \\
\hline Cichla monoculus (Spix) & tucunaré & piscivorous & $0,5 \%$ (low) \\
\hline Colossoma macropomum (Cuvier) & tambaqui & herbivorous & $0,2 \%$ (low) \\
\hline Liposarcus pardalis (Castelnau) & acari bodó & detritivorous & $0,1 \%$ (low) \\
\hline Mylossoma duriventre (Cuvier) & pacu comum & herbivorous & $7,0 \%$ (high) \\
\hline Pellona flavipinnis (Valenciennes) & apapá branco & piscivorous & $6,4 \%$ (high) \\
\hline Plagioscion squamosissimus (Heckel) & pescada branca & piscivorous & $2,0 \%$ (intermediate) \\
\hline Pygocentrus nattereri (Kner) & piranha caju & piscivorous & $1,2 \%$ (intermediate) \\
\hline Schizodon fasciatum (Agassiz) & aracu comum & herbivorous & $2,0 \%$ (intermediate) \\
\hline
\end{tabular}


In the laboratory, filets free of scales, skin, and bones were drawn from fish so as to be frozen $\left(-20^{\circ} \mathrm{C}\right)$ in amber-glass bottles with teflon-septum caps. Extraction of OPI residues from the filets was carried out according to methods 304-E1 (extraction) and 304C2 (cleanup) of the American Food and Drug Administration (FDA) suitable for fatty matri$\operatorname{ces}^{3}$. This solid/liquid multiresidue extraction procedure allows for the simultaneous extraction of several nonpolar pesticides. As a result, only parental OPI were quantitatively recovered since it is impossible to extract polar metabolites of OPI with this procedure.

We slightly modified the FDA methods to better fit our needs. Hereafter are the few modifications we brought. For the extraction step, $30 \mathrm{~g}$ (wet weight) of fish filet were grounded with $60 \mathrm{~g}$ of anhydrous sodium sulfate $\left(\mathrm{Na}_{2} \mathrm{SO}_{4}\right)$. We determined the quantity of fish according to fat content (Junk, 1985) to avoid overwhelming the retention capacity of the cleanup column. For the concentration step, we used a rotary evaporation system instead of the Kuderna-Danish concentrator recommended by the FDA since we achieved better results with the former device. For the cleanup step, we followed instructions for the methylene chloride elution system, although we only used eluants "2" and "3" (50\% methylene chloride, $0,35 \%$ acetonitrile, $49,65 \%$ hexane (v/v/v) and $50 \%$ methylene chloride, $1,5 \%$ acetonitrile, $48,5 \%$ hexane $(\mathrm{v} / \mathrm{v} / \mathrm{v})$, respectively). As we collected all of our analytes through these two eluants, the eluant "1" proposed by FDA was useless in our case. All reagents were ACS grade; they were concentrated and tested for contamination beforehand.

Cleaned extracts were concentrated to 2 $\mathrm{ml}$ prior to analysis. OPI analyses were conducted with a Varian 3800 gas chromatograph (GC). Our system was equipped with an autosampler (Varian 8200), a splitless glass insert ( $0.5 \mathrm{~mm}$ ID), a SPB-5 fused silica capillary column (Supelco, $30 \mathrm{~m}$ lenght, 0,25 mm ID and $0,25 \mu \mathrm{m}$ film) protected by a deactivated and uncoated fused silica guard column (Siltek,
$5 \mathrm{~m}$ length, 0,25 $\mathrm{mm}$ ID), and provided with a thermoionic specific detector (TSD). TSD response was monitored during routine analyses by external standards. Injector and TSD temperatures were set at 230 and $300{ }^{\circ} \mathrm{C}$, respectively. The temperature programming of the GC oven was as follow : initial temperature, $80{ }^{\circ} \mathrm{C}$, initial hold time, $120 \mathrm{~s}$; ramp rate of 40 ${ }^{\circ} \mathrm{C} \cdot \mathrm{min}^{-1}$ to $150{ }^{\circ} \mathrm{C}$, hold time, $60 \mathrm{~s}$; ramp rate of $4{ }^{\circ} \mathrm{C} \cdot \mathrm{min} .{ }^{-1}$ to $200{ }^{\circ} \mathrm{C}$, hold time, $300 \mathrm{~s}$; and ramp rate of $40{ }^{\circ} \mathrm{C} \cdot \mathrm{min} \cdot{ }^{-1}$ to $290{ }^{\circ} \mathrm{C}$, final hold time, $360 \mathrm{~s}$; total run time, 30,5 min. Helium was the carrier gas $\left(1,5 \mathrm{ml} \cdot \mathrm{min}^{-1}\right)$ while nitrogen was the make-up gas $\left(28,5 \mathrm{ml} \cdot \mathrm{min}^{-1}\right)$. Each analysis was made in triplicate, with an injection volume of $2 \mu 1$.

Recovery rate ( \pm standard deviation) for each OPI was $110 \% \pm 10 \%$. Detection limits for chlorpyrifos, malathion, and methyl-parathion were $2,45,1,65$, and $3,20 \mathrm{ppm}$ (concentrations of the extract injected in the GC), respectively. Concentrations of insecticides in fish (wet weight) were calculated separately in order to compare each one to its own ADI. Undetected compounds were assumed to be present at half the detection limit (see above) of the GC rather than absent from specimens.

In order to further our understanding of the ichtyofauna contamination, we tested some biological factors that may influence OPI levels in specimens. We first checked for the existence of interspecific differences. Then, we explored two factors (diet and lipid content) which might explain these interspecific differences. Determination of diet (Tab. 1) was made according to literature (Goulding and Carvalho, 1982; Soares et al., 1986; Ruffino and Isaac, 1995; Junk et al., 1997; Ferreira et al., 1998). Lipid contents were estimated according to Junk (1985), by using figures for the low water season (Tab. 1). For all parameter tested, we used Kruskal-Wallis' tests and a set of Wilcoxon-Mann-Whitney's tests every time a Kruskal-Wallis test showed a significant difference. In addition, Kendall's rank correlation tests were used to verify the existence of a relation between the lipid content and the OPI level in filets.

${ }^{3}$ These methods are found in the Pesticide Analytical Manual, volume 1. This document is available on the Web at the following URL : http://vm.cfsan.fda.gov/ frf/pami3.html (see chapter 3). 


\section{RESULTS}

\section{Description of the fish sample}

Our results indicate that OPI found in the specimens analyzed are at trace levels. As depicted by the histograms of Figure 2, which illustrate distributions of the
120 specimens according to their OPI concentrations, most specimens are very slightly contaminated albeit a restricted few show much more higher concentrations. Moreover, the exponential pattern of distributions clearly justifies the use of nonparametric tests for further statistical data analysis.

Figure 2 - Statistical distributions of the 120 specimens according to their concentrations in chlorpyrifos, malathion, and methyl-parathion. sk = skewness, $\mathrm{s}_{\mathrm{x}}{ }^{2}=$ variance, $\theta=1 / \mu$ (parameter of the exponential law, where $\mu$ is the mean).

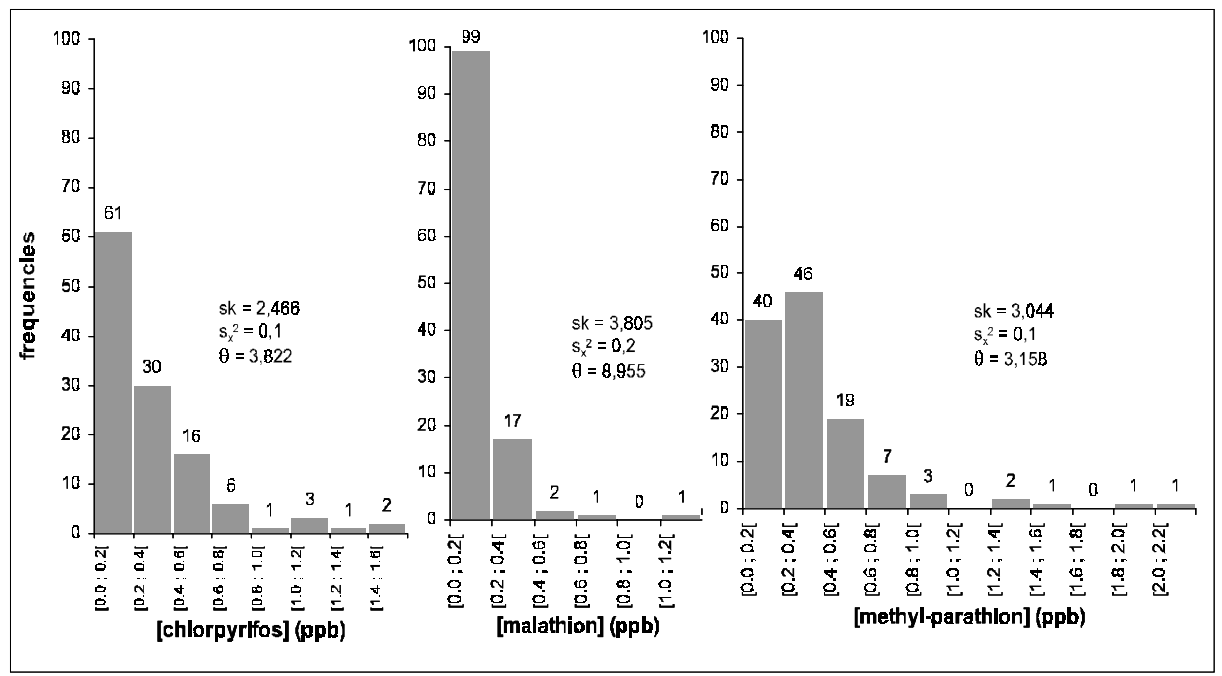

Table 2 lists some statistical parameters for the whole sample and for each species. Considering the whole sample, the majority of specimens are contaminated to a detectable level by chlorpyrifos and methyl-parathion (59,2\% and $68,3 \%$, respectively), although this is not true in the case of malathion (only $25,8 \%$ detected). Furthermore, $20 \%$ of the sample show no detectable contamination by any of the three OPI. When specimens are divided according to their species (Tab. 2), it appears that the occurrence and the difference between the particular mean and median vary from one species to another. These observations suggest specific trends, which become more obvious ( 2 words) from the boxplots of Figure 3.

\section{Daily doses absorbed by popula- tions and comparison to acceptable daily intakes}

According to Cerdeira et al. (1997), the average fish meat consumption of a riverine population living near Santarém is about 220 $\mathrm{g} \cdot \mathrm{d}^{-1}$ inhabitant (a point is missing). Although it is likely that urban populations consume a smaller quantity of fish per day (Shrimpton and Giugliano, 1979; Smith, 1979; Amoroso, 1981), we extrapolated this figure to the whole region of Santarém. Table 3 estimates OPI daily doses ingested by local populations via their fish consumption.

Acceptable daily intakes (ADI) for chlorpyrifos, malathion, and methyl-parathion 
Table 2 - Statistical parameters for the whole sample and for each species.

\begin{tabular}{|c|c|c|c|c|c|c|c|}
\hline Group & $\begin{array}{c}\text { Size } \\
\mathrm{n} \\
\end{array}$ & Insecticide & $\begin{array}{l}\text { Range } \\
(\mathrm{ppb})\end{array}$ & $\begin{array}{c}\text { Median } \\
(\mathrm{ppb})\end{array}$ & $\begin{array}{l}\text { Mean } \\
(\mathrm{ppb})\end{array}$ & $\begin{array}{l}\text { Std dev. } \\
( \pm \mathrm{ppb})\end{array}$ & $\begin{array}{c}\text { Occurrence } \\
(\%)\end{array}$ \\
\hline \multirow{3}{*}{ whole sample } & \multirow{3}{*}{120} & chlorpyrifos & $0,1-1,4$ & 0,1 & 0,3 & 0,3 & 59,2 \\
\hline & & malathion & $0,0-1,0$ & 0,1 & 0,1 & 0,1 & 25,8 \\
\hline & & methyl-parathion & $0,1-2,1$ & 0,2 & 0,3 & 0,3 & 68,3 \\
\hline \multirow{3}{*}{ C. monoculus } & \multirow{3}{*}{15} & chlorpyrifos & $0,1-1,0$ & 0,1 & 0,2 & 0,3 & 60,0 \\
\hline & & malathion & $0,0-0,2$ & 0,1 & 0,1 & 0,1 & 13,3 \\
\hline & & methyl-parathion & $0,1-0,4$ & 0,2 & 0,2 & 0,1 & 53,3 \\
\hline \multirow{3}{*}{ C. macropomum } & \multirow{3}{*}{15} & chlorpyrifos & $0,1-1,1$ & 0,2 & 0,3 & 0,3 & 66,7 \\
\hline & & malathion & $0,0-0,7$ & 0,1 & 0,1 & 0,2 & 40,0 \\
\hline & & methyl-parathion & $0,1-0,5$ & 0,3 & 0,3 & 0,1 & 86,7 \\
\hline \multirow{3}{*}{ L. pardalis } & \multirow{3}{*}{15} & chlorpyrifos & $0,1-0,9$ & 0,1 & 0,2 & 0,2 & 46,7 \\
\hline & & malathion & $<\mathrm{DL}-0,4$ & $<\mathrm{DL}$ & $<\mathrm{DL}$ & 0,1 & 13,3 \\
\hline & & methyl-parathion & $0,1-0,7$ & 0,2 & 0,2 & 0,2 & 80,0 \\
\hline \multirow{3}{*}{ M. duriventre } & \multirow{3}{*}{15} & chlorpyrifos & $0,1-0,6$ & 0,1 & 0,2 & 0,2 & 60,0 \\
\hline & & malathion & $<\mathrm{DL}-0,2$ & 0,1 & 0,1 & 0,1 & 6,7 \\
\hline & & methyl-parathion & $0,1-0,7$ & 0,3 & 0,3 & 0,2 & 60,0 \\
\hline \multirow{3}{*}{ P. flavipinnis } & \multirow{3}{*}{15} & chlorpyrifos & $0,2-1,4$ & 0,4 & 0,5 & 0,3 & 80,0 \\
\hline & & malathion & $0,1-1,0$ & 0,1 & 0,2 & 0,2 & 40,0 \\
\hline & & methyl-parathion & $0,4-2,1$ & 0,8 & 0,9 & 0,5 & 100,0 \\
\hline \multirow{3}{*}{ P. squamosissimus } & \multirow{3}{*}{15} & chlorpyrifos & $0,1-1,4$ & 0,2 & 0,3 & 0,3 & 66,7 \\
\hline & & malathion & $<\mathrm{DL}-0,2$ & 0,1 & 0,1 & 0,1 & 33,7 \\
\hline & & methyl-parathion & $0,1-0,4$ & 0,2 & 0,2 & 0,1 & 53,3 \\
\hline \multirow{3}{*}{ P. nattereri } & \multirow{3}{*}{15} & chlorpyrifos & $0,1-0,3$ & 0,1 & 0,1 & 0,1 & 46,7 \\
\hline & & malathion & $<\mathrm{DL}-0,3$ & 0,1 & 0,1 & 0,1 & 6,7 \\
\hline & & methyl-parathion & $0,1-0,5$ & 0,2 & 0,2 & 0,1 & 60,0 \\
\hline \multirow{3}{*}{ S. fasciatum } & \multirow{3}{*}{15} & chlorpyrifos & $0,1-1,1$ & 0,1 & 0,2 & 0,3 & 53,3 \\
\hline & & malathion & $<\mathrm{DL}-0,3$ & 0,1 & 0,1 & 0,1 & 53,3 \\
\hline & & methyl-parathion & $0,1-0,4$ & 0,2 & 0,2 & 0,1 & 53,3 \\
\hline
\end{tabular}

a: Determines the ratio of specimens in which the compound has been positively detected.

$<\mathrm{DL}$ : Smaller than the detection limit

are fixed at $0,01,0,02$, and $0,02 \mathrm{mg} \cdot \mathrm{kg}^{-1}$, respectively (Lu, 1995). Assuming a hypothetical body weight of an adult consumer of $60 \mathrm{~kg}^{4}$, we calculated that critical daily doses for chlorpyrifos, malathion, and methyl-parathion are $0,6,1,2$, and $1,2 \mathrm{mg} \cdot \mathrm{d}^{-1}$, respectively. Considering the latter figures, it is obvious that even the maximum daily doses to which local populations are exposed (Tab. 3) are far smaller than those required to reach ADI. In fact, daily fish consumption would have to increase by ca. 1 950, 5 450, and 2600 times to reach ADI of chlorpyrifos, malathion, and methyl-parathion, respectively. In other words, with such "security margins", probabilities of attaining the critical doses stated above with fish from the sampled market are infinitesimal.

\section{Biological factors influencing The contamination ( 2 words) level of fish by OPI}

According to Kruskal-Wallis' tests, interspecific differences that we already suspected from boxplots of Figure 3 proved to be very highly significant for all three OPI. Further analysis using Wilcoxon-Mann-Whitney's tests indicated that these differences are caused by 1) P. flavipinnis (higher than all other species) and $P$. squamosissimus (higher than $L$. pardalis, $P$. nattereri, and $S$. fasciatum, but lower than $P$. flavipinnis) in the case of chlorpyrifos; 2) P. flavipinnis (higher than all other species, except $C$. macropomum and $S$. fasciatum) and L. pardalis (lower than all other spe-

${ }^{4}$ Based on a study made in a small community along the Tapajós River (Brasilía Legal), the average Amazonian adult female weight is $58 \mathrm{~kg}$ and the average adult male weight is $63 \mathrm{~kg}$ (D. Mergler, personal communication). 
Figure 3 - Distribution boxplots for each species analyzed. $\mathrm{O}=$ outlier value $(>1,5$ interquartile range) ${ }^{*}=$ extreme value $(>3$ interquartile range).

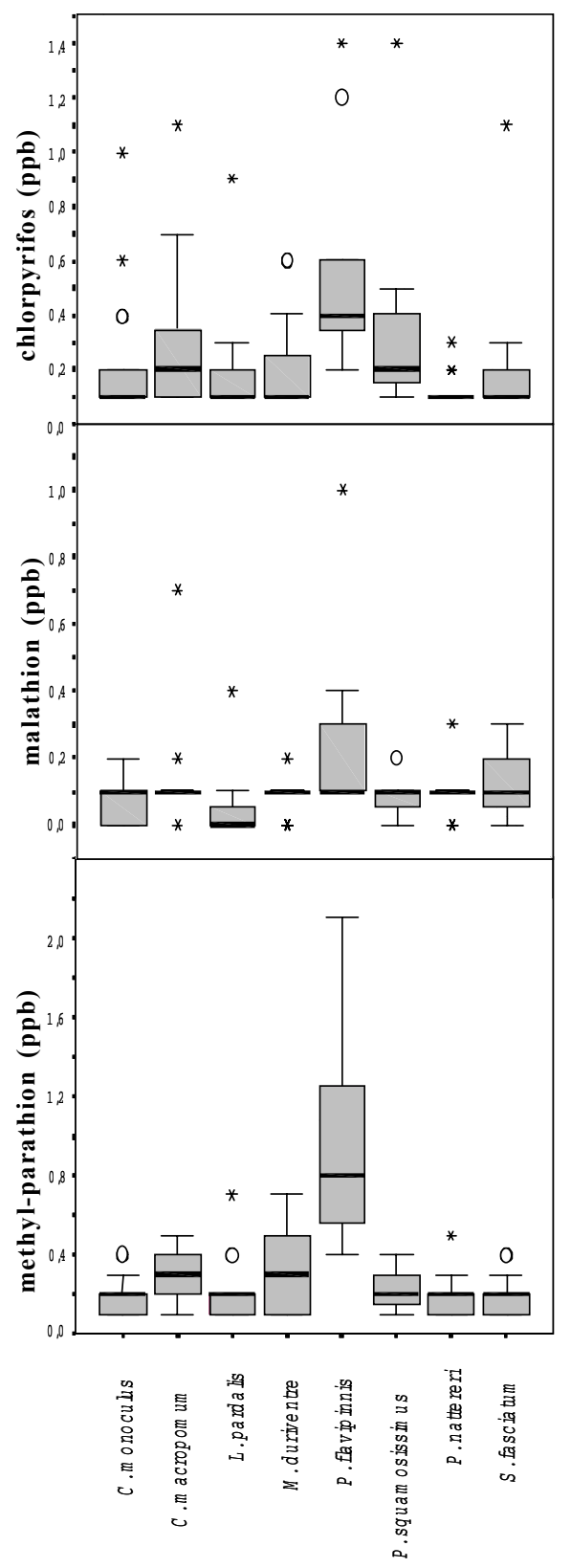

cies, except $C$. monoculus) in the case of malathion; 3) P. flavipinnis (higher than all other species) and $C$. macropomum (higher than $C$. monoculus, $P$. nattereri, and $S$. fasciatum, but lower than P. flavipinnis) in the case of methyl-parathion. Although these observations show that some species may be marked out from the batch sample, none of them is as repeatedly distinct as $P$. flavipinnis. The latter may hence be seen as greatly responsible for the interspecific differences registered.

Influence of both biological factors tested (diet and lipid content) in order to explain interspecific differences varies according to the insecticide at stake. According to Kruskal-Wallis' tests, diet only seems to exert an influence in the case of malathion, differences being very highly significant. Results of Wilcoxon-Mann-Whitney's tests clearly point out that the detritivorous diet distinguishes itself (lower) from the two other dietary groups, the latter remaining statistically undiscernible.

Regarding the lipid content, differences between groups are at least highly significant (Kruskal-Wallis) for all three OPI. Results of Wilcoxon-Mann-Whitney's tests indicate that these differences are caused by the high lipid content group, which distinguishes itself (higher) from other groups, chlorpyrifos and methyl-parathion respectively showing as highly and very highly significant. The situation with malathion is less obvious since the high lipid content group is different (higher) from the low lipid content group, without there being any significant difference between these groups and the intermediate one. Furthermore, Kendall's rank correlation tests show that if there is a relation of an at least significant nature between the lipid content and the contamination level, this relation remains weak according to Kendall's tau-b coefficients (t).

\section{DISCUSSION}

\section{Choice of the study period and representativeness of the sample}

Being tightly linked to the seasonal water cycle of the Amazon River, agriculture on várzeas is subjected to wide fluctuations in the course of a year (Fig. 1). During the high 
Table 3 - Estimation of daily doses of OPI ingested by populations of the region of Santarém when consuming fish from the market ${ }^{\mathrm{a}}$.

\begin{tabular}{|c|c|c|}
\hline \multirow{4}{*}{$\begin{array}{l}\text { Minimal doses }\left(n g \cdot d^{-1}\right) \\
\text { (based on the less contaminated specimen) }\end{array}$} & chlorpyrifos & 22,0 \\
\hline & malathion & $<\mathrm{DL}$ \\
\hline & methyl-parathion & 22,0 \\
\hline & chlorpyrifos & 22,0 \\
\hline \multirow{2}{*}{$\begin{array}{l}\text { Median doses }\left(n g \cdot d^{-1}\right) \\
\text { (based on the median of the whole sample) }\end{array}$} & malathion & 22,0 \\
\hline & methyl-parathion & 44,0 \\
\hline \multirow{3}{*}{$\begin{array}{l}\text { Average doses }\left(n g \cdot d^{-1}\right) \\
\text { (based on the mean of the whole sample) }\end{array}$} & chlorpyrifos & 66,0 \\
\hline & malathion & 22,0 \\
\hline & methyl-parathion & 66,0 \\
\hline \multirow{3}{*}{$\begin{array}{l}\text { Maximal doses }\left(\mathrm{ng} \cdot \mathrm{d}^{-1}\right) \\
\text { (based on the most contaminated specimen) }\end{array}$} & chlorpyrifos & 308,0 \\
\hline & malathion & 220,0 \\
\hline & methyl-parathion & 462,0 \\
\hline
\end{tabular}

a: Based on a daily fish consumption of $220 \mathrm{~g}$ (Cerdeira et al., 1997).

$<\mathrm{DL}$ : Smaller than the detection limit

water season, most várzea soils are flooded and agricultural activities are scarce, being often confined to small gardens on stilts (Padoch and Pinedo-Vasquez, 1999). However, as heavy rainfalls are frequent during this period of the year, runoff with the few pesticides applied is prone to occur. On the contrary, during the low water season, agriculture and pesticide applications reach their optimum as plenty of soil is available for crops. However, because precipitations are less abundant during this season, pesticide runoff may be lower in comparison with the high water season.

In a comprehensive study of pesticide contamination in fish, it would have been relevant to conduct several sampling campaigns along the year in order to assess each set of environmental and agricultural conditions. However, keeping in mind that we conducted a preliminary study on this issue, we rather focused on a single period we considered the most critical. For several reasons, we estimated that the low water season could be that critical period during which fish contamination may be at its highest. First, and as explained above, it is expected to find the highest pesticide consumption at that time of the year. Second, the averaged daily precipitations in September are about $3 \mathrm{~mm}$ (Xie and Arkin, 1996, in Zeng, $1999)^{5}$. Hence, although fish contamination is more likely to come from wind drift and vola- tilization during that time, insecticides runoff is also likely to occur. Third, as fish populations are more confined due to the drying-up of some aquatic habitats, fishing activities increase during the low water season (Ohly and Junk, 1999). Probabilities are thus higher to consume a contaminated specimen during that period of the year.

The eight species collected cannot give an exhaustive picture of the Lower Amazon's ichtyofauna biodiversity. Indeed, more than sixty fish species are found in the several markets of Santarém (Isaac et al., 1996; Ruffino et al., 1998). Nevertheless, only ten species out of those sixty account for $80-86 \%$ of the catches landed in Santarém (Isaac et al., 1996; Ruffino et al., 1998). Since the eight species collected during this study are among the latter, we can reasonably assume that our sample is representative of the commercial species currently found in Santarém during the low water season.

\section{Sanitary hazards linked to fish consumption}

As far as OPI are concerned, the daily fish consumption does not appear to represent a health hazard for the Amazonian populations since detected levels of these compounds are far below their ADI. Several considerations

${ }^{5}$ Averaged data for September, from 1985 to 1993. 
may however temper this reassuring conclusion. Only three OPI among the most commonly used pesticides in Santarém were analyzed, thus neglecting other potentially harmful products. Moreover, only parental compounds were quantitatively recovered by the FDA procedures, letting metabolite concentrations of these insecticides unknown. This situation constitutes an important lack of this study when considering the high vulnerability of OPI to in vivo transformations (IPCS, 1986; Gallo and Lawryk, 1991) and the great toxicity of some of these metabolites. Although it is a widely accepted assertion that metabolites are rapidly excreted by living organisms because of their low affinity for lipid matrices, it was demonstrated that some fish species may bioaccumulate malaoxon (a metabolite of malathion) because they lack the enzymes required for its hydrolysis (Areechon and Plum, 1990). However, it is unlikely that analyzed fish contain a sufficiently high concentration of metabolites to reach critical doses. Since the quantity of OPI found in specimens is many times lower than their respective ADI, the fish would have to accumulate much greater quantities of metabolites than those detected for their parental compounds, a situation not likely to occur (Hall and Kolbe, 1980; Takase and Oyama, 1985; Cunha Bastos et al., 1999).

A last limit still deserves attention. Each insecticide was individually compared to its particular ADI. Now, considering that most specimens are contaminated with more than one compound and given the existence of synergistic or additive effects between some OPI (Gallo and Lawryk, 1991), we must be careful when drawing conclusions from norms established for a single insecticide. However, one may argue that thanks to the wide security margins we defined, it is unlikely that additive or synergistic effects of OPI present in fish reach a deleterious level. Nevertheless, the concomitant absorption of pesticides from other alimentary sources such as fruits or vegetables may remain dangerous. In a similar way, the possible presence of other neurotoxic chemicals in fish - particularly organomercuric compounds (Lebel et al., 1997) - may cause unsuspected synergistic effects which are not covered by this study.

\section{Determination of biological factors affecting the contamina- tion levels in fish}

Although we found that the contamination level varies from a species to another, the exact causes of this situation still remain unknown. On the one hand, statistical tests have shown that no difference was induced by the diet in the case of chlorpyrifos and methyl-parathion. However, the same biological factor seems to induce a very highly significant difference in the case of malathion. While this difference is due to the detritivorous group represented by L. pardalis alone, it is yet dubious to draw any conclusion from a single species as differences could arise from other specific factors. On the other hand, statistically significant differences caused by the lipid content also remain ambiguous. By correlating the lipid contents of fish with their contamination levels, we expected to find a concomitant augmentation of both variables, a phenomenon which was assessed by Kendall's rank correlation tests. However, these tests have shown but a weak relation between those variables. Moreover, only the high lipid content group distinguished itself from the other groups. It appears that the differences are mainly due to $P$. flavipinnis since $M$. duriventre - the other species comprised in the high-lipid group - presents relatively low OPI levels in spite of its higher lipid content. Thus, although the lipid content may be partially responsible for the interspecific differences, other influent factors which were not assessed in this study may intervene to a larger extent. The specific metabolism of fish could represent a relevant answer to the differences observed, but there is yet no study dealing with toxicokinetic aspects of Amazonian fish. One may also note that the spatial distribution of specimens $-\mathrm{a}$ parameter that was not assessed in this study - can account for the differences observed.

The absence of any significant difference caused by the diet in the case of chlorpyrifos and methyl-parathion may suggest some indications about the phase and the way these OPI are introduced in the aquatic environment, and as to how they contaminate the ichtyofauna. 
Despite the interest of these prospective leads, we remain careful regarding the validity of the following hypotheses mainly because of the low contamination levels and the relatively high number of specimens with undetected OPI.

Two phenomena may explain the similar contamination levels of the different dietary groups : 1) an even distribution of contaminants among all food sources for fish, which would allows equal body burdens via biomagnification; 2) the presence of OPI in the water column which may be readily absorbed by bioconcentration. Both phenomena imply the presence of dissolved chlorpyrifos and methyl-parathion, forms unlikely to be introduced in water by runoff or leaching from treated soils since these two insecticides are known to be well adsorbed onto soil particles (Wauchope, 1978; Agnihotri et al., 1981). Now there are only two possible ways to find dissolved OPI in the water column. One means is through volatilization, atmospheric transport, and precipitations (Racke, 1992; Bidleman, 1999; Van Dijk and Guicherit, 1999). These routes play a major role in OPI transportation, especially during a period of low rainfall. We can also suspect some bioconcentration arising from a slow desorption process of OPI from the sediments, which constitute an important sink for these contaminants associed with soil particles (Hughes et al., 1980; Sabharwal and Belsare, 1986; Bhushan et al., 1997).

Between both hypotheses on bioaccumulation stated above, bioconcentration seems to be the principal route through which OPI are absorbed by fish. Indeed, OPI are not transfered along the food chain to a great extent because they are easily decayed by the in vivo digestive processes of animals (IPCS, 1986), plant metabolism (Sabharwal and Belsare, 1986; Racke, 1992), and even chemi$\mathrm{cal} /$ microbial processes in sediments and flooded soils (Sabharwal and Belsare, 1986; Adhya et al., 1987), thus tempering biomagnification processes. Moreover, there is some evidence that bioconcentration is the most relevant route of contaminant exposure in the aquatic habitat (Chiou et al., 1977; Bruggeman et al., 1981).

\section{CONCLUSION}

Focusing on the agricultural pollution of the ichtyofauna by OPI, this study has shown that detected concentrations of some of these insecticides in fish are several times lower than their respective ADI. It thus appears that the contamination of the ichtyofauna by OPI is unlikely to occur to a problematical extent in the region of Santarém. Pellona flavipinnis, a large and high lipid-content piscivorous species, was the most contaminated fish of our sample. Still, the exploratory and partial nature of this study should not be overlooked. Concerning the assessment of the contamination by other classes of pesticides or by OPI metabolites, we allowed ourselves to speculate on the wide security margins we determined. Nevertheless, we insist on the fact that either this statement or the one on the plausible absence of deleterious synergistic or additive effects must imperatively be validated by complementary studies. Besides, our conclusions are only applicable to the present OPI amounts in use and the consequences of a greater pesticide consumption on várzeas remain unknown.

To further address the issues raised by this study we strongly encourage local scientific authorities to develop a monitoring program aiming at the assessment of contamination levels of a wide array of pesticides in the ichtyofauna. Particularly, it would be of first interest to characterize the seasonal fluctuations of the contamination, considering the huge hydrological modifications taking place throughout the year and their impact on várzea's agriculture. It would also be interesting to determine the actual effect of floods on the fate of pesticide residues in the soils of várzeas : a further degradation (hydrolysis) or a desorption toward the water column.

\section{ACKNOWLEDGMENTS}

This study was supported by the Natural Sciences and Engineering Research Council of Canada (NSERC) and the International Development Research Center of Canada (IDRC). The authors would like to thank Dr. Mauro Luis Ruffino from Projeto IARA at Santarém 
for his helpful advices, the students of the Laboratório de Biologia Ambiental at the Federal University of Pará (UFPa) in Santarém for their implication on the field, and Pierre Cayer and Sophie Tran from the Institute of Environmental Sciences at the University of Québec at Montréal (ISE-UQAM) for their help in the laboratory. Revision of the manuscript was made by Emmanuel Roy.

\section{LITERATURE CITED}

Adhya, T.K.; Wahid, P.A.; Sethunathan, N. 1987. Persistence and biodegradation of selected organophosphorus insecticides in flooded versus non-flooded soils. Biology and Fertility of Soils, 4(1):36-40.

Agnihotri, N.P.; Pandey, S.Y.; Jain, H.K.; Srivastava, K.P. 1981. Persistence, leaching and movement of chlorfenvinphos, chlorpyrifos, disulfoton, fensulfothion, monocrotophos and tetrachlorvinphos in soil. Indian Journal of Agricultural Chemistry, 14(1-2):27-31.

Amoroso, M.C.M. 1981. Alimentação em um bairro pobre de Manaus. Acta Amazônica, 11(3):supplement of $43 \mathrm{pp}$.

Areechon, N.; Plum, J.A. 1990. Sublethal effects of malathion on channel catfish, Ictalurus punctatus. Bulletin of Environmental Contamination and Toxicology, 44:435-442.

Bhushan, R.; Thapar, S.; Mathur, R.P. 1997. Accumulation pattern of pesticides in tropical fresh waters. Biomedical Chromatography, 11(3):143-150.

Bidleman, T.F. 1999. Atmospheric transport and air-surface exchange of pesticides. Water, Air, and Soil Pollution, 115(14):115-166.

Bruggeman, W.A.; Martron, L.B.J.M.; Koolman, D.; Hutzinger, O. 1981. Accumulation and elimination kinetics of di-, tri-, and tetrachlorobiphenyls by goldfish after dietary and aqueous exposure. Chemosphere, 10:811-815.

Cerdeira, R.G.P.; Ruffino, M.L.; Isaac, V.J. 1997. Consumo de pescado e outros alimentos pela população ribeirihha do
Lago Grande de Monte Alegre, PA Brasil. Acta Amazônica, 27(3):213-228.

Chiou, C.T.; Freed, V.H.; Schmedding, D.W.; Kohnert, R.L. 1977. Partition coefficient and bioaccumulation of selected organic chemicals. Environmental Science and Technology, 11(5):475-478.

Cowgill, U.M.; Gowland, R.T.; Ramirez, C.A.; Fernandez, V. 1991. The history of a chlorpyrifos spill : Cartagena, Colombia. Environment International, 17:61-71.

Cunha Bastos, V.L.F.; Silva Filho, M.V.; Rossini, A.; Cunha Bastos, J. 1999. The activation of parathion by brain and liver of a Brazilian suckermouth benthic fish shows comparable in vitro kinetics. Pesticide Biochemistry and Physiology, 64(3):149-156.

Ecobichon, D.J. 1991. Toxic effects of pesticides. In : Amdur, M.O.; Doull, J.; Klaassen, C.D. (Ed). Casarett and Doull's toxicology. The basic science of poisons. $4^{\mathrm{e}}$ édition. Mc Graw-Hill, New York. pp. 565-622.

Ferreira, E.J.G.; Zuanon, J.A.S.; dos Santos, G.M. 1996. List of commercial fish species from Santarém, State of Pará, Brazil. NAGA, The ICLARM Quarterly, 19(3):4144.

Ferreira, E.J.G.; Zuanon, J.A.S.; dos Santos, G.M. 1998. Peixes comerciais do Médio Amazonas, região de Santarém, Pará. Cooleção Meio Ambiente: Série Estudos Pesca. 18. Instituto Brasileiro do Meio Ambiente e dos Recursos Naturais Renováveis (IBAMA), Brasília. 212 pp.

Furch, K. 1997. Chemistry of várzea and igapó soils and nutrient inventory of their floodplain forests. In : Junk, W.J. (Ed). The Central Amazon Floodplain. Ecological Studies. 126. Springer-Verlag, Berlin. pp. 47-67.

Gallo, M.A.; Lawryk, N.J. 1991. Organic phosphorus pesticides. In : Hayes, W.J.; Laws, E.R. (Ed). Handbook of pesticide toxicology. 2: Classes of pesticides. Academic Press Inc., San Diego. pp. 917-1123.

Goulding, M.; Carvalho, M.L. 1982. Life history and management of the tambaqui 
(Colossoma macropomum, Characidae): An important Amazonian food fish. Revista Brasileira de Zoologia, 1:107-133.

Hall, R.J.; Kolbe, E. 1980. Bioconcentration of organophosphorus pesticides to hazardous levels by amphibians. Journal of Toxicology and Environmental Health, 6:853-860.

Hughes, D.N.; Boyer, M.G.; Papst, M.H.; Fowle, C.D.; Rees, G.A.V.; Baulu, P. 1980. Persistence of three organophosphorus insecticides in artificial ponds and some biological implications. Archives of Environmental Contamination and Toxicology, 9:269-279.

IPCS. 1986. Organophosphorus insecticides: A general introduction. World Health Organization (WHO), Geneva.

Isaac, V.J.; Milstein, A.; Ruffino, M.L. 1996. A pesca artesanal no Baixo Amazonas: análise multivariada da captura por espécie. Acta Amazônica, 26(3):185-208.

Junk, W.J.; Soares, M.G.M.; Saint-Paul, U. 1997. The fish. In : Junk, W.J. (Ed). The central Amazon floodplain. Ecological Studies. 126. Springer-Verlag, Berlin. pp. 385408.

Klaassen, C.D.; Eaton, D.L. 1991. Principles of toxicology. In : Amdur, M.O.; Doull, J.; Klaassen, C.D. (Ed). Casarett and Doull's toxicology. The basic science of poisons. $4^{\text {th }}$ edition. McGraw-Hill, New York. pp. 12-49.

Lebel, J.; Roulet, M.; Mergler, D.; Lucotte, M.; Larribe, F. 1997. Fish diet and mercury exposure in a riparian Amazonian population. Water, Air and Soil Pollution, 97:3144.

Lu, F.C. 1995. A review of the acceptable daily intakes of pesticides assessed by WHO. Regulatory Toxicology and Pharmacology, 21:352-364.

Ohly, J.J. 1987. Untersuchungen über die Eignung der natürlichen Pflanzenbestände auf den Überschwemmungsgebieten (várzea) am mittleren Amazonas, Brasilien, als Weide für den Wasserbüffel (Bubalus bubalis) während der terrestrischen Phase des Ökosystems.
Göttinger Beiträge zur Land- und Forstwirtschaft in den Tropen und Subtropen, 24.

Ohly, J.J.; Junk, W.J. 1999. Multiple use of Central Amazon floodplains: reconciling ecological conditions, requirements for environmental protection, and socioeconomic needs. Várzea, 13:283-299.

Padoch, C.; Pinedo-Vasquez, M. 1999. Farming above the flood in the várzea of Amapá : Some preliminary results of the Projeto Várzea. Várzea, 13:345-354.

Racke, K.D. 1992. Degradation of organophosphorus insecticides in environmental matrices. In : Chambers, J.E.; Levi, P.E. (Ed). Organophosphates. Chemistry, fate and effects. Academic Press, San Diego. pp. 4778.

Ruffino, M.L. 1996. Potencialidades das várzeas para os recursos pesqueiros : uma visão sócio-econômica e ecológica. Empresa Brasileira de Pesquisa Agropecuária (EMBRAPA) - Conselho Assessor Regional Norte, Boa Vista, Roraima, Brazil.

Ruffino, M.L.; Isaac, V.J. 1995. Life cycle and biological parameters of several Brazilian Amazon fish species. NAGA, The ICLARM Quarterly, 18(4):41-45.

Ruffino, M.L.; Isaac, V.J.; Milstein, A. 1998. Fisheries ecology in the lower Amazon: a typical artisanal practice in the tropics. Ecotropica, 4:99-114.

Sabharwal, A.K.; Belsare, D.K. 1986. Persistence of methyl parathion in a carp rearing pond. Bulletin of Environmental Cotamination and Toxicology, 37:705-709.

Saint-Paul, U.; Bayley, P.B. 1979. A situação da pesca na Amazônia Central. Acta Amazônica, 9(4):109-114.

Salati, E. 1985. The climatology and hydrology of Amazonia. In : Prance, G.T.; Lovejoy, T.E. (Ed). Key environment : Amazonia. Pergamon Press, New York. pp. 18-48.

Scatena, F.N.; Walker, R.T.; Homma, A.K.O.; De Conto, A.J.; Ferreira, C.A.P.; Carvalho, R.A.; Neves da Rocha, A.C.P.; 
Don Santos, A.I.M.; De Oliveira, P.M. 1996. Cropping and fallowing sequences of small farms in the "terra firme" landscape of the Brazilian Amazon : a case study from Santarém, Pará. Ecological Economics, 18:29-40.

Shrimpton, R.; Giugliano, R. 1979. Consumo de alimentos e alguns nutrientes em Manaus. 1973-4. Acta Amazônica, 9(1):117-141.

Smith, N.J.H. 1979. Pesca no Rio Amazonas. INPA/CNPq, Manaus. 154 pp.

Soares, M.G.M.; Almeida, R.G.; Junk, W.J. 1986. The trophic status of the fish fauna in Lago Camaleão, a macrophyte dominated floodplain lake in the middle Amazon. Amazoniana, 9(4):511-526.

Soumis, N.; Roulet, M.; Lucotte, M. 2000. Characterization of pesticide consumption in the county of Santarém, Pará, Brazil. Acta Amazônica, 30(4):615-628.

Takase, I.; Oyama, H. 1985. Uptake and bioconcentration of disulfoton and its oxidation compounds in carp, Cyprinus carpio L. Journal of Pesticide Science, 10(1):47-53.

Torres, J.P.M.; Pfeiffer, W.C.; Markewitz, S.; Panse, R.; Malm, O.; Japenga, J. 2002. Dichlorodiphenyl trichlorocthane in soil, river sediment, and fish in the Amazon in Brazil Environmental Reseaech, 88(2): 134-139.

Van Dijk, H.F.G.; Guicherit, R. 1999. Atmospheric dispersion of current-use pesticides : A review of the evidence from monitoring studies. Water, Air, and Soil Pollution, 115(1-4):21-70.

Wauchope, R.D. 1978. The pesticide content of surface water draining from agricultural fields - A review. Journal of Environmental Quality, 7:459-472.0

Zarin, D.J. 1999. Spatial heterogeneity and temporal variability of some Amazonian floodplain soils. Várzea, 13:313-321.

Zeng, N. 1999. Seasonal cycle and interannual variability in the Amazon hydrologic cycle. Journal of Geophysical Research, 104(D8):9097-9106. 
